\title{
Intergenerational Messages as Sign of Wisdom of Active Polish and Czech Older Learners
}

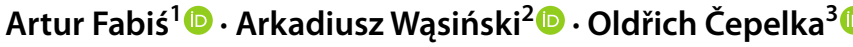

Accepted: 21 June 2021 /Published online: 16 July 2021

(c) The Author(s) 2021

\begin{abstract}
The goal of the paper is to identify the message in letters written by Polish and Czech seniors. The letters were subject to qualitative analysis. The method used was the analysis of the inspired texts-letters written by older people to the younger generation, which may become a didactic tool for the younger generations to learn from the biographies of seniors. The result of the analysis is a list of categories reflecting the main aspects dominating in the letters. These categories are: message addressed to a younger generation, important events and people in individual life story, reflection upon the meaning of life and concerns and challenges in the course of life. All the seniors express their affirmation of family, share ethical reflections on their relationships with other people and on passing. Thus, the main message of the letters is a call to cherish family relationships, nurture relations with other people and show respect to others.
\end{abstract}

Keywords Letters · Inter-generational message $\cdot$ Learning from old age $\cdot$ Values

\section{Theoretical Introduction}

Letters written to real as well as fictional persons are often analysed within many scientific disciplines. And even though the ways of generating and communicating messages have been changing with time - from ancient drawings on the rocks, signs and symbols carved in stone, through traditional letters written on paper to digital

Artur Fabiś

artur.fabis@up.krakow.pl

Arkadiusz Wąsiński

arkadiusz.wasinski@now.uni.lodz.pl

Oldřich Čepelka

oldrich.cepelka@tima-liberec.cz

1 Pedagogical University of Krakow, Krakow, Poland

2 University of Lodz, Lodz, Poland

3 Faculty of Humanities, Charles University, Prague, Czech Republic 
messages created online - they still play the same role of conveying information the author thinks is important to the recipient(s).

For seniors in particular, letter writing is a classic form of communicating with their social environment and in this context, it even goes beyond the framework of communication within and between generations. Thus, it is justified to explore the role of letters in the context of a meeting with other human. The value of this encounter lies in the opportunity for the authors to get to know and understand the other person but also in the chance to learn about and understand themselves. Thus, it is an important element of education and self-education for each participant of the mediated communication: the author of the letter, its direct recipient and, finally, third party readers who become recipients too, though unintended and accidental.

Mager (2019) notices that storytelling contributes to improved well-being in older adults, expressed as acceptance of ageing and the anticipated stages of the late adulthood. It can be assumed that writing a letter which includes biographical elements is therapeutic. For the recipient (direct and indirect) it is of cognitive value. It gives the chance to learn about the inaccessible, personal areas of life of the letter's author, his or her experiences, reflections and life wisdom, which the reader can confront with their own experiences and knowledge of life (Szarota, 2019).

Contemporary letter analyses focus mainly on the content, though the form itself is also a source of scientific explorations or an additional point of reference for the content analysis. Letters written by older adults seem to have cognitive value as seniors often engage in reflections, need to evaluate life, tend to include retrospective references to their own biography and the biographies of significant others or to their experience gained during life struggles, especially the loss of the loved ones or illness (Tedeschi et al., 1998). This results in the holistic concept of self and identity as well as coherent beliefs about other people and important, general issues (Addis \& Tippett, 2008; Staudinger, 2001). Therefore, a common motive in the seniors' letters is the attempt to make a positive balance of their life in the light of lives of people who formed their social environment and the intent to communicate (to young people in particular) the "wisdom" view of the value and the meaning of life, validated with authentic, personal biographical experiences (Sternberg, 2003; Baltes et al., 2004).

The letters emphasise the profound meaning of life experience and wisdom this experience has produced. This wisdom is treated as a value which determines, to a great extent, the attractiveness and effectiveness of communication with people from the younger generations who think in the categories of the pre-figurative culture (Mead, 1972).

What is special about the letters written by older adults is their willingness to participate in the life of others also through one-way, non-interactive written messages the content of which is important from the point of view of human existence (Fabiś et al., 2017). According to the terror management theory, the awareness of the approaching end of life is expressed in the desire to remain in the memory of other people - loved ones, friends and even strangers - to leave a trace of one's presence and achievements, which would symbolically prolong one's existence beyond death (Pyszczynski et al., 2002). Remaining in the memories of other people involves the belief that, through decisions or actions made in their own life, seniors have contributed to some good in the lives of others.

In case of older people, the recipients are often their grandchildren (Dryll et al., 2017; Tokarska, 2019). This paper focuses on a similar form of communication 
but the recipients are not only grandchildren but also other representatives of the younger generations in two neighbouring countries: Poland and Czech Republic.

\section{Methodological Grounds}

The analysis presented herein was inspired by the research project conducted several years ago and published in the Journal of Family History (Fabiś et al., 2017). The project utilised the method of content analysis of the inspired texts - letters written by seniors. The structure of meanings conveyed in the messages of Polish seniors to other generations was characterised; the meanings were explored from the perspective of biographical experiences of the respondents. "Such formula of the research provided an opportunity to learn about seniors' individual references to their own biographies from the point of view of their idea of life, sensitivity, value systems, decisions that determined their fate. It also allowed getting to know the socio-cultural reality present in various periods of their life, inscribed in their experiences" (Ibidem, p. 329).

The authors are convinced that in this context, not only further studies into the nature of the inter-generational messages of Polish seniors are of cognitive value but the area of the research should be expanded to include intergenerational messages of seniors from other European countries. Thus, researchers from Poland and Czech Republic decided to join their efforts to include letters written by Czech seniors and jointly analyse all the texts.

The goal of the research was to identify the key categories which are essential for both Polish and Czech seniors as they think about the approaching end of their lives. These categories will constitute the content of the messages addressed to the younger generation. Even though Poles and Czechs are aware of the historical bonds between their nations which have relatively good neighbourly relations based on the international economic cooperation and the exchange of intellectual achievements, they are also aware of the differences and historical animosities between them. These differences result mainly from cultural distinctness identified with the history, traditions and different social atmosphere in both countries - the atmosphere created based on the awareness of the uniqueness of the native language, mentality, national identity and the unique sense of national community. The most differentiating characteristics is religiousness. Poles are the most religious nation in Europe whereas Czechs - the least. Given the above, it seemed interesting to study similarities and differences revealed in the letters of Czech and Polish seniors and to show the values which for them are crucial in everyone's life, which they wanted to emphasise while writing to the young people. In other words, exploring the essence of life expressed by the narrators mainly through pointing to the values, characteristics and attitudes will allow to read the intergenerational message from the old to the young. It is assumed that letters, as the form of intergenerational communication, give young people the chance to include seniors' recommendations in their own life management strategies. For this reason, the analysis focused on the components of the messages dedicated to younger generations: truths of life valued by the seniors, values and principles of ethical conduct, recommended directions and ways to model one's own life. The general research problem was formulated as follows: What are the 
messages active Polish and Czech older learners communicate in their letters to representatives of the young generation?

\section{Methods and Organisation}

The research material are letters written by seniors to the younger generations. The authors are Czech and Polish older adults who live in their natural social environments in Czech Republic and Poland. The letters were inspired by the following phrase: "My life - my death". The statement was intended to motivate the authors to a deep biographical reflection which would facilitate individual confrontation with two existentially critical phenomena: life and death. As seniors refer to the above mentioned phenomena, their narratives began to focus on the critical aspects of their biographical experiences, decisions and choices made in different periods of life, as well as personal evaluation of their own conduct viewed in the light of their attitude towards other people. Given the nature of the research problem, the study was performed using the qualitative approach and was set within the constructivist paradigm (see Lincoln \& Guba, 2000, p. 168-173; Kubinowski, 2011, p. 101-105; Lee, 2012). At the ontological level, this paradigm is based on the subjective perception of the reality, which assumes the validity of many locally constructed and reconstructed realities. Epistemologically, it is based on the transactional character of the content analysis which is a co-creation of the subjects engaged in the in-depth examination of the part of the reality in question. In the methodological layer, the constructivist paradigm refers to the hermeneutic interpretation and understanding of the seniors' letters as the source material. The research was conducted using the qualitative content analysis of the inspired documents (Bednarz-Łuczewska \& Łuczewski, 2012, pp. 97-106). Thus, the object of the study are the intergenerational messages constructed on the grounds of an in-depth reflection on the values and the meaning of one's own life, treated as individual messages conveyed in the letters written by seniors to young people.

The analysis of the qualitative data - the content of the letters - was performed according to M. Lichtman's 3C's. Thus, the goal of the data analysis was to move from raw data, through identification of categories to identification of important concepts or themes (Lichtman, 2013, p. 254). For the qualitative analysis, the investigator triangulation was used (Flick, 2007). Investigators represented different scientific environments from Poland and Czech Republic. The Nvivo 12 pro software was used for the analyses. All generalizations are limited exclusively to the narrators.

\section{Methods of Content Analysis}

The narrative formula used by seniors in their letters combines the freedom of expression, synthetically formulated, self-reflective references to biographical facts and attempts to create a message to young people, revealing different aspects of human life. In this context, the letter analysis is quite a unique - in the structural 
sense - narrative which requires interpretative subtlety and sensitivity from the researchers. Due to editorial limitations, the paper focuses mainly on the discussion resulting from interpretations made at the stage of formulating the concept.

The qualitative data analysis was inspired by M. Lichtman's 3C's concept (Lichtman, 2013, p.252). The structure of categories was developed in the following stages:

- initial coding of letter texts and revision of coding to develop a coding system used for the analysis of the whole research material,

- ordering the codes to develop an initial list of subcategories and to modify this list based on the thorough comparative analysis of the subcategories,

- grouping the subcategories to create a list of categories and review the categories and subcategories generated; the intent was to identify the categories which reflect the research problems and refer to the themes identified in the letters,

- moving from the categories to concepts treated as the final stage of interpretation of meanings which constitute the intergenerational message as a whole.

The qualitative content analysis was based on the open coding type (Patton, 1990, pp. 381-382). Coding was performed jointly by all the researchers. In this process, the following codes were identified: place/context, defining the situation, respondents' perspective, process, respondents' activity, event, relationship and social structure (Bogdan \& Biklen, 2003, pp. 162-168). The categories and subcategories generated from the letters are descriptive categories and they point out to the multi-aspect references seniors made to the value of life recognised in: awareness of own family roots and mental connection to the lives of family members from the previous generations; the role of the loved ones with whom seniors bind their lives and important life affairs; acknowledging the logic of life, which involves constant response to the challenges stimulating personal development; constant reflection on the nature of human existence and the mystery of death as its integral component; the content of the message addressed to young people, to which the seniors feel predestined because of their awareness of the value and the meaning of life as well as the desire to share their life experience (Lincoln \& Guba, 1985, pp. 341-342).

\section{Localization and Procedure}

The letters were obtained in the same way in both countries - through contact with seniors who participated in voluntary workshops organized in life-long learning institutions such as universities of the third age, senior clubs etc. The study was conducted at the same time but independently among the Polish and Czech seniors. The following Polish seniors took part in the research: Tadeusz 82 years, Tamara 63 years, Tatiana 75 years, Zdzisława 84 years, Zofia 79 years, Zygfryda 77 years; the respondents in the Czech group were: Emilka 83 years, Eulalie 68 years, Helena 77 years, Josef H. 87 years, Marenka 78 years, Josef 83 years. A researcher from Poland collected the letters from the Polish seniors, while a researcher from Czech - from the Czech respondents. Participation in the study was absolutely voluntary. Seniors who wished to take part, wrote their letters at home. Once they had finished (several days later), they handed their letters to the researcher in 
the life-long education centre where the study was initiated. Participation in the research did not involve announcing this fact by the researcher to other senior students of the education facility. However, the respondents were not obliged to keep their participation confidential and could inform others about it.

During one of the classes, the research project was presented and the seniors were invited to take part in it and write a letter to a young person. Those who were interested received a guide with the rules of writing the letter. The research idea and rules were presented in the same way in every Polish and Czech group. The researchers intentionally did not provide detailed information. The assumption was not to guide seniors to avoid limiting their freedom of expression so that they could refer to these issues in a way that was coherent with their individual sensitivity, cultural identity, experiences, life balance, life philosophy and other components of their wisdom.

The seniors could determine the recipients of their letters. The form, length, scope and content was not imposed. The letters chosen for the analysis were those addressed to younger persons - grandchildren, children, relatives - because the assumption was that only intergenerational messages from older to younger individuals will be studied. Other sampling criterion was the age of the authors, that is, 60 years or more. The oldest respondent was 87 years old. The sample consisted of 12 letters, 10 of which were written by women ( 5 from Poland and 5 from Czech) and 2 by men ( 1 from Poland and 1 from Czech). The study was conducted from September 2018 to June 2019.

\section{Structure of Categories and Subcategories Generated During Letter Analysis}

A structure of categories and subcategories was generated during the letter analysis. There are following main categories: 1. The story of my life, 2. Other people in my life, 3. Life as a challenge, 4. Reflection on the sense of life, 5. My message. Additionally, the subcategories were identified (Scheme 1). These categories reflect different aspects of how seniors see their life and what do they identify as valuable. The way they are formulated reflects the personal character of the letters in which seniors share their memories and reflections based on their biographical experiences.

\section{The Story of My Life}

This category consists of two basically different, complementary ways of referring to one's own biography. Biographical facts form a subcategory which includes the codes of place, event and situational context. Thus, they are the codes ordered according to short statements in which seniors list important facts to give the recipients some information. Seniors recall the biographical facts which were important for them due to their impact on their further life. These facts refer to deaths of family members (a child, a husband/wife), illness, traffic accident of a loved one, career and important life decisions. Descriptions of the family history, in turn, include codes ordered according to the statements with detailed descriptions of the important 


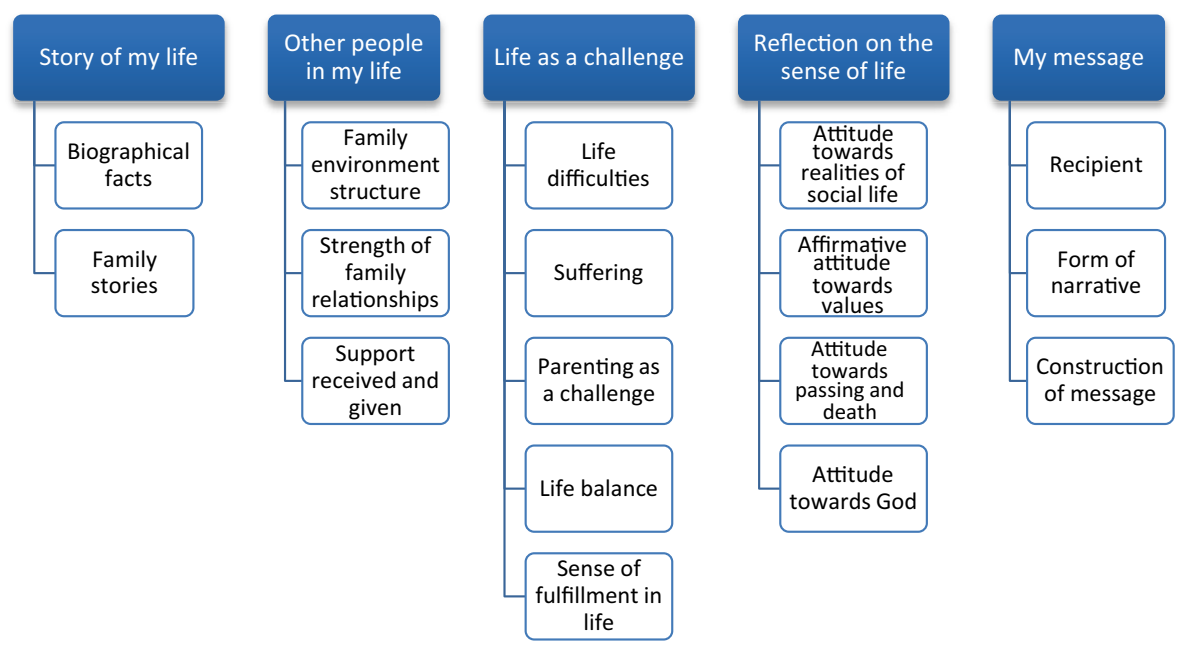

Scheme 1 Structure of categories and subcategories identified in coding process. Source: Authors' own compilation

biographical facts. In these descriptions seniors try to explain the biographical context of certain biographical facts. While reading these parts, one can think that the narrators wanted to present a clear picture of their experiences, the ways they had coped with difficult situations as well as their attitudes towards these events back then and now. The second subcategory is not a counterpoint for the first one but rather complementary, providing interpretation and introducing the young recipients to the unknown world of personal experiences of the authors.

The narrators tell the story of their life to show - on the example of their own biographical experiences - how to live and what mistakes to avoid. The important part of the letters were detailed stories from the authors' childhood, adolescence and adulthood, which pointed out to some breakthrough events (in the eyes of the narrators).

- I could still remember my father. He was extremely selfless and strong, almost tireless and my mom said he had a horsepower. There are testimonies to that, we saw it as children: when the horses got scared and run into the river with the chariot, father was able to separate them and calm them down. When the neighbour's roof broke under the heavy snow, he immediately got up and fixed it in the night. He never said "NO" to anyone in need. "Fortune favours the brave". And that was him. (Emilka, CZ)

- Studies, professional promotion, moving, hiring a nanny, these were the events which needed many conversations and compromises in our marriage. (Tamara, $P L)$

The authors of the letters describe the roles and events they think were important or breakthrough and emphasise the importance of planning and achieving the goals 
set in adulthood. They also point out to the necessity of making decisions which determine the whole life, such as retiring or moving to a nursing home. Polish seniors also pointed out to illness and death as critical life events.

- I set different goals at different stages of my life. The first important decision in my life was the choice of career (...) I had always wanted to be financially independent and make independent professional decisions. (...) To have a group of loyal friends was also one of the goals I had set and achieved. (...) I also grew up to make the decision about my retirement. (Tamara, $P L$ )

- I kept thinking about a nursing home even though my niece and my sister were helping me. But I decided to go to the nursing home and I am glad because I could not make it at home. (Zofia, PL)

- A difficult moment in out life was my husband's illness. He had to apply for a pension. (...) A year after my husband had died, I too had a severe heart attack. I underwent treatment and then, the same diseases. (Zdzistawa, PL)

- I had a good wife, we respected each other very much. The disease came 15 years after we got married and it destroyed my life a little. My wife had been dialysed for 15 years, then the transplantation after which she lived 8 more years. The death of my Wiktoria was the greatest pain. (Tadeusz, PL)

\section{Other People in My Life}

This category reveals the multi-aspect picture of interpersonal relationships of the seniors in their social environment (mainly family). This picture presents the dynamics and strength of these relationships and seniors' role in them. The category consists of the three subcategories which expose the complex character of human relationships in the context of family structure, the strength of family relations and support given to and received from others.

What is characteristic for the letters is the focus on the network of relationships established within the family environment. Seniors, especially those from the Czech group, emphasised the fact of having a spouse, children and grandchildren. It is worth to point out that the context of these statements ordered as codes in the "Family environment structure" subcategory conveys not only satisfaction from being a member of a multigenerational family but also shows that this fact is valued as personal achievement. Having children and grandchildren is viewed as leaving a lasting mark in the world. The "Strength of family relationships" subcategory was generated out of the wider sequence of codes of: relationships, social structure, activity, situation definitions and process. It includes authors' descriptions and reflections regarding their: a) spouses with whom they shared or have been sharing many years of life and b) children and grandchildren. In the first group of codes (a), the narrators referred to the following aspects: positive or negative attitude towards a spouse, the importance of marital love in the context of a fulfilled love, missing the late spouse or a friend not seen for a long time. In the second code group (b), the seniors referred to the meaning of close relationships with their children or grandchildren; they also expressed concern that due to their health, they are a burden to their children who have to care about them. 
Within the third subcategory of "Support received and given", the seniors point out to the importance of both receiving and providing support. They clearly refer to support as: a) the fact realised in daily circumstances by people from the direct family or institutional environment, b) certainty that there is an actual possibility to receive support when necessary, c) conviction that there is no such possibility at all, d) individual activity of supporting others, mentioned in the context of care for the grandchildren and mutual care within marriage.

In both direct and indirect messages, family is presented as the highest value. Seniors view it as a community bound by mutual love and nurtured relationships between its members. The letters contain numerous references to marital relationships as priceless for creating the right family atmosphere and for ensuring strong, lasting family bonds. For the seniors, family is the warranty of safety and support in every situation.

- Also, my one and only, my beloved wife has been with me all my life. We used to tell good and bad things to each other, and we survived. Unlike today - first problem appears and people divorce. We have been through all this but we have stuck together and it has strengthen us. And now, we have been together for over 60 years and we still love each other. (Josef, CZ)

- (...) these were the events where many conversations and compromises in our marriage were needed. Fortunately, my husband could always be convinced and he does not regret it today, even though for him it meant additional responsibilities and a job change. (Tamara, PL)

In the late adulthood, relationships with the younger generations, especially children and grandchildren, become more important, even though they have completely different nature. In general, a relationship with any person can be of value and Polish and Czech seniors write about it in their letters.

- I am glad that it looks that today, the relations between my daughters and me are good and I am very grateful for it. (Eulalie, CZ)

- Together we celebrate all church and family celebrations. We have friendly relationships with the families of our sons-in-law. (Tamara PL)

- My niece helped me a lot, for example to pay the bills, do some shopping, drive to the church, the doctor. (Zofia, PL)

\section{Life as a Challenge}

This category is very wide and covers the whole sequence of codes of event, situation definition, activity, thinking patterns and perspectives of the seniors. It consists of five subcategories. Their common element is life presented as a sequence of different boundary situations important from the existential point of view. These situations involve physical and spiritual suffering, they distort the present life and even bring the risk of losing it. In the context of these statements, the desire to live motivates to take efforts to face these situations in a constructive way. Every situation 
is treated as a new challenge which, if responded to, gives the chance to grasp the meaning of related events and experiences. Even though not welcomed, each new challenge shapes a unique biographical experience through which seniors not only describe their life story but also express themselves and confirm the value of overcoming obstacles as their personal achievement.

The "Life difficulties" and "Suffering" subcategories reveal the tension between the past events and experiences which are the integral component of seniors' biographies and present boundary situations which are not yet resolved. In both time perspectives, these situations are the source of suffering, either past one and therefore constituting life experience treated as a value in itself, or present one with unpredictable course of the future events. Thus, "Life difficulties" include situations connected with hardships experienced in adolescence and early adulthood. Seniors emphasised the value of surviving against all odds and referred to the reality of living during:

(a) the World War II (direct threat to life, death of loved ones, hunger, tragic living conditions),

(b) communism (permanent food rationing, low income, poor living conditions, life in isolation due to travel restrictions, lack of religious freedom).

"Suffering" subcategory, in turn, refers to necessary physical, psychical or/and spiritual suffering caused by: illness or serious injuries due to a traffic accident, death of a spouse, lack of purpose in life, loneliness and anticipated loss of independence and physical pain of dying.

Another life challenge mentioned by the seniors is parenting. Even though it is presented as personal achievement, they emphasise that it was a long-term effort they had taken to secure adequate conditions for their children's development and to guide them once they had left home. Categories that correspond with this perspective of successful confrontation with various challenges at different stages of the lifespan are "Life balance" and "Sense of fulfilment in life". The difference is in the structure of the letter narrative. When evaluating their lives, seniors focused on listing and rating their achievements to which they assign different wages and existential meaning. As for the second subcategory, seniors concentrated mainly on their marriage, family and professional achievements viewed as something they consider a success, something they are satisfied with or even proud of.

One of the challenges mentioned are critical situations and existential concerns the narrators have experienced in their middle and late adulthood. Loneliness and loss is what they have struggled the most with. They have dominated other, also frequently mentioned difficulties of living in a communist country. These problems were described by both Czechs and Poles.

- I have no one and here I also have no close person with whom I would not feel lonely. (Tadeusz, PL)

- When my husband died I was left alone and it was very hard. (Zofia, PL) 
- With time, the relations at work were not good enough, the management changed and a new boss came and he was a communist. I stopped liking him and I had to go. (...) We could not travel much during communism but when we were free, we went with the boys wherever we could. (Josef, CZ)

- It was not easy in totalitarianism, there were different sanctions and there was no religious freedom. (Emilka, $\mathrm{CZ}$ )

- She lived in the times which may seem archaic to you but I actually liked it. Even though one could not travel, people had less money and when they bought something, they used it for many years but they were happy, these things does not matter... (Eulalie, $C Z$ )

Regardless of the difficult living conditions during their youth and early adulthood, many seniors evaluate their lives positive. They declare they feel fulfilled and happy about their past and present life, satisfied with their achievements. The greatest of these achievements is family live, in particular their parenting experiences.

- I have lived a beautiful life and you all are my joy. My last words will be: "God, we praise You”. (Emilka, CZ)

- From the perspective of the years, I think my life was happy and successful, though not without difficult moments. (Tamara, PL)

- There was the wedding and then the most beautiful experience, that is, your birth, my son, and after four years of intense work I gave birth to you, my daughter. (...) I am happy that I have children I could rely on, especially now, when I am old. (Zdzistawa, PL)

- I am very happy for my children because they have their own families. Now, I have nine grandchildren, including two great-grandchildren. (Zygfryda, $P L$ )

- We enjoyed our children and experienced joys and worries with them. We believed deeply and that is how we raised our children. (...) But our daughters were very smart, they got only the best grades and today they have university diplomas and proper families. Pavel's daughter is a nun. (Emilka, CZ)

- Our daughters finished university, they were about to start their own lives. Like all parents, we cared a lot about their adulthood, the choice of their life partners. We could only support them, offer them our help and advice as they were building their "nests". (Tamara, PL)

\section{Reflection On the Sense of Life}

The "Reflection On the Sense of Life" category consists of four complex subcategories within which seniors reveal their views on the essence of life in different contexts and at different level of reflection. This reflective attitude towards the value and the meaning of life can be observed in regards to four aspects of existence: respected life values, relationship with God, attitude towards passing and attitude towards socio-cultural changes.

In their letters, seniors tend to avoid direct references to the realities of the social life. However, they notice the dynamics of the socio-cultural changes which radically 
transform the social reality and make it more and more confusing and foreign. Two seniors declared they were convinced that their life wisdom will not be useful for the young people. When commenting the socio-political realities of living under the communist system, they evaluated them as negative.

The greatest number of statements were coded as the "Affirming attitude towards values" subcategory. Undoubtedly, it is worth pointing out that seniors focused more on spiritual and sacral values than on vital and utilitarian ones. Save for health and career treated as important life values, they highlight values connected with acknowledging the beauty of nature and the importance of having other people around. These values are: optimistic approach to the world and other people, love towards others, the good of others as a guiding principle, ability to forgive, raising children as a sign of responsibility for their development, family as a community of people who support and love one another and faith in God which gives meaning to individual existence.

Seniors' messages regarding passing and death show that they have accepted the approaching end of life. However, it is not careless thinking about the future but rather a deep reflection over the meaning of their lives in the face of death and its possible metaphysical perspective treated as the source of hope that they will pass on to another life dimension. Those who declare that they believe in God, reveal religious attitude towards death. In this context, it is worth pointing out that seniors who openly declared their faith expressed gratitude to God for the gift of life which for them is a pilgrimage, a sanctifying path to God.

In the perspective of spiritual and sacral values, there are statements in which seniors express their opinion about passing and God.

- It was not easy in totalitarianism, there were different sanctions and there was no religious freedom. (Emilka, $\mathrm{CZ}$ )

- We could not travel much during communism but when we were free, we went with the boys wherever we could. (Josef, CZ)

- We all know that we must die one day - I simply don't know where and how. (Josef, CZ)

- Home alone, I thought a lot about death. (Tatiana, PL)

- None of the young generations is interested in advices of the older-for you, we are the "old school", "from the old times". (Marenka, CZ)

- Everything is gone - the only thing that remains are traces of work and love... (Josef, CZ)

- I know very well that one has to die. I am not afraid of death, only suffering which may come before death. But I know that I can go through everything with God's help. (Zofia, PL)

- I am looking forward to meeting my husband and my parents, and everyone who has already passed away. I tell God: "You promised that there are many dwellings in heaven and you have never lied". (Emilka, CZ)

As mentioned before, family is the priority value. It is expressed in the seniors' memories of their parents who are presented as persons who built, materially and symbolically, their family home, created the atmosphere of full understanding and 
childhood happiness, engaged in daily work and bravely faced everyday struggles. Following this example, the narrators' families are also full of love, understanding and often sacrifice for the children. The narrators usually recall difficult living conditions like small apartments, insufficient earnings, lack of basic food products but also remember their joy as managed to get material goods they had worked hard for. But the greatest happiness were the births of their children and grandchildren, accompanying them in their growth and raising them.

- (...) my military service has come to an end and, save for the suitcase with my uniform, I took home a beautiful blonde with a little treasure. (Josef, CZ)

- In the past, people lived simple lives and reached their goals with their own strength and efforts. They valued their work which was very tedious but they passed their wisdom gained through experience on to the next generations. (Josef, CZ)

- I met your dad and everything went its own way, as it used to be. There was the wedding and then the most beautiful experience, that is, your birth, my son, and after four years of intense work I gave birth to you, my daughter. (Zdzistawa, PL)

- I am very happy for my children because they have their own families. Now, I have nine grandchildren, including two great-grandchildren. (Zygfryda, PL)

- What I remember the most is when you were born. It was just wonderful. I knew right away that I will love you infinitely. (Eulalie, CZ)

Career and health are next in the hierarchy of values. They are seen as the conditions necessary for normal social functioning. It should be pointed out that Polish seniors tend to write about their lack of health as the reason of their failures. What is very interesting is that Czech seniors emphasise one more value which is practically absent in the letters of Polish narrators: faith in God and the role of God's providence in this life.

- The disease came 15 years after we got married and it destroyed my life a little. My wife had been dialysed for 15 years, then the transplantation after which she lived 8 more years. The death of my Wiktoria was the greatest pain. (Tadeusz, $P L)$

- I am ready to die. Everyone should be! I have everything ready, the grave, the funeral arrangements. The priest knows too. (Tadeusz, PL)

- In the past, people lived simple lives and reached their goals with their own strength and efforts. They valued their work which was very tedious but they passed their wisdom gained through experience on to the next generations. (Josef, CZ)

- I often pray for peace, for the homeland, for politicians so that they fight for the good of everyone, for religious freedom and christian principles. I am old, I do not have many joys so I need to use every opportunity that brings joy and enriches. (Emilka, CZ)

- May God help you with everything, He is that what is above us and what we all feel exists. (Eulalie, CZ) 
- Faith is a gift from God, it does not come right away, it is often connected with mistakes, disappointment and pain. But no gift should be rejected and you will be surprised how much joy it will bring you, how much delight and how many surprises. (Marenka, CZ)

\section{My Message}

In the "My Message" category, indications as to who is the recipient the message were taken into account. The character of each letter was considered - whether it contained personalised reference to a certain individual or was more general, addressed to an anonymous young person. Different types of recipients determine the form of narrative and the structure of the message. In the first case, seniors tend to initiate a direct "dialogue" with the recipient and are more open when describing personal circumstances related to their family biography. The narrative is then dominated by reflections on personal experiences situated mainly within the sphere of family life. In the other case, the language of the narrative is more distanced, it is the communication with anonymous recipient. The focus of the narrative are more general reflections about life, references to the socio-cultural and economic processes presented by seniors in coincidence with the political reality before and after the system transformation in their countries. The biographical motives are mentioned less frequently and are more of a background constructions, complementing the main message.

The majority of the message recipients are grandchildren and great-grandchildren; the rest are family members or loved ones, addressed as "dear" or "beloved". In single cases, letters are general and addressed to anonymous "young" or "students".

During the analysis we noticed quite unexpected situation of constructing the message in a direct or indirect form. Even though all seniors were willing to share their stories and experiences with the letter recipients, not everyone formulated their life philosophy and conclusions directly. In some letters, the authors did not feel the need or desire to influence the way young people think or act, even if they presented their own perspective of what it means to live well. It does not mean that they tried to hide their life philosophy from the readers. But in some letters the message was constructed in such a way so that the story focused on personal experiences of the narrators who, however, did not try to generalise them. It seems that they intended for the letters to encourage the recipients to independent search for important and timeless life values. We assume that in this context the direct character of the message was to inspire a deeper reflection over the essence of human life.

Of course, in the course of reflection on the content, a dominant trend emerges of building the narrative based on how life is understood by the narrators. It seems, however, that the authors do not intend to expose any leading thought treated as life principle which would be valuable for others. They rather want to share their reflections generated by their individual experiences. The attitude revealed in these letters does not imply that they are convinced their life wisdom should be acknowledged and implemented by others. Seniors who used direct form to convey their messages, take a step further. Based on their personal experiences, they generalise their 
biography and reflections, and present them as a reliable, verified by life and valuable life philosophy. They expect that it will not only be noticed but also internalised by the recipients.

Among the direct messages, one can find calls to recognise the value of work and persistent action, strive to achieve happiness and remain cheerful, take advantage of one's civil freedom and travel, take care of one's health and admire the nature. But the main message of these letters is love as the key principle in human life. In this context, considering the good of others is emphasised.

- So appreciate what you have and travel, but remember that family is important. (Josef, CZ)

- Love was, is and will be solid as a rock. St. Paul writes beautifully about love - I would like you to read his words, they are deep and true. Remember this! (Marenka, CZ)

- That is why I want to tell you something, maybe you will share this with your children and grandchildren. This one I know - one has to always try to live in a way so that others feel good with us, never despair and not to look back. (Zygfryda, $P L)$

- I want to tell young people to respect one another, to start their own families and love one another. (Tadeusz, PL)

Indirect messages refer mainly to faith and the value of family. In the first case, seniors declare their faith in God and assure the recipients of His real presence and love and the eternal life that extends beyond death. As for the family, it is presented as an irreplaceable area of community life, a reference system and a refuge from the world, the space where one experiences love, mutual support and accountability.

- For me, family has always been the priority and I hope you can feel it and notice it too. I am still here for you and I wish to be for a long time. (Marenka, CZ)

- We thank God that He has always blessed us and accompanied us with His grace. We have always tried to remain faithful to God. (Emilka, CZ)

- I can always rely on the family and I am glad that I have it, I am even a greatgrandfather. (Josef, CZ)

Other contexts of the indirect messages refer to self-creation and self-care. There are also existential motives which direct thinking towards the course of life and passing.

- Please, remember that I will always be watching over you from above. (Helena, $P L)$

- Ania, I know that life does not last forever - with peace and hope I am waiting for each new day which may be my last one (...) we have passed on faith in God (...) (Zygfryda, PL) 


\section{Structure of Concepts as Interpretation of Seniors' Messages Conveyed in Letters}

The analysis of the letters has shown several main areas seniors refer to when constructing individual narratives about their life and things they consider important (Scheme 2). These areas are identified - within the concept of M. Lichtman's 3C's - with more general concepts revealing the key aspects of the seniors' messages addressed to the young people. This aspect of the analysis is an attempt to embrace the meaning of the whole of the message shared by the seniors in their letters. The concepts presented in Scheme 2 show three separate, though not excluding and even interfering and coexisting, main thoughts and life philosophies derived from the narrators' biographical experience. It must be emphasised that according to seniors, these concepts are what makes human life meaningful. The messages formulated in the letters are treated by seniors as the sign of their wisdom and a symbolic, selfless gift to benefit others.

The nature of the seniors' messages (which lead to diverse interpretations) within different concepts reveals some significant but also subtle aspects of their selfreflexive references to the value and the meaning of life.

(a) The call to recognise family as the source of joy and satisfaction in life is the sign of deep awareness of seniors and their belief that family as a setting where social life takes place and where the authentic presence of other people, love and responsibility can be experienced. This experience is presented in the most clear and meaningful way in most of the messages. Seniors often refer to their family history, providing more complex descriptions of the reality of life of their grandparents, parents and siblings, marked with the trauma of the World War II and communism. In these letters, the perspective of the family history clearly

Scheme 2 Structure of concepts expressing seniors' message treated as central component of their intergenerational message. Source: Authors' own compilation

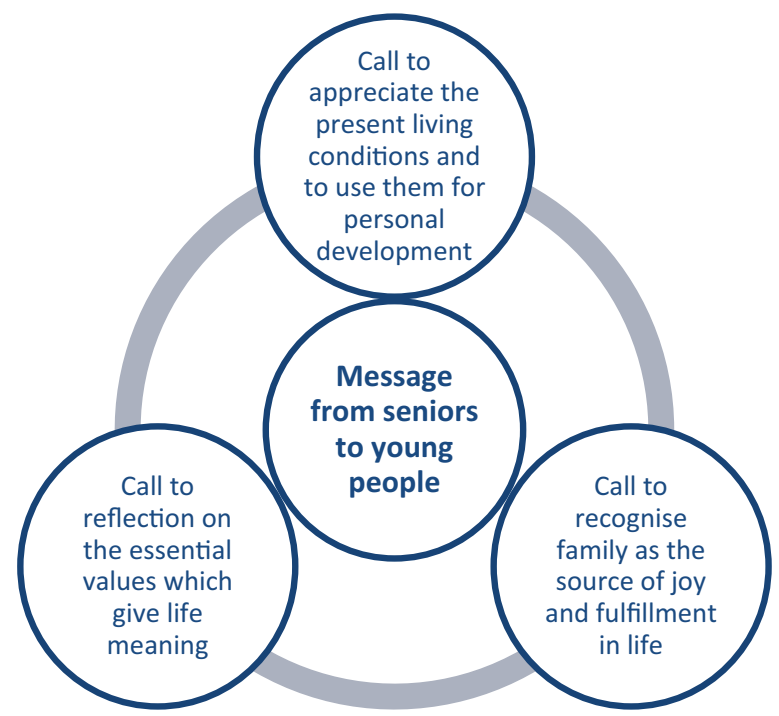


dominates. The narrators set the important meanings and values, attitudes or educational goals within it. Family, understood as lasting, strong and the most meaningful bonds with the loved ones, is described as a special type of reality which marks every part of their biography, their identity, mentality, sensitivity to others, their role models or attitudes. It is presented as an inherent component of their journey towards development and personal maturity. In this context, family life described by the seniors is still an important and relevant experience to which they not only keep returning in their memories but which guides them in their daily life. This affects their messages - the authors are less moralistic and mainly share their joy from personal experiences the source of which is the family;

(b) The call to appreciate the present living conditions and use them to pursue individual development results from the experience of living in the post-war reality which marked the narrators' childhood and adolescence and, first of all, life in the communist countries during early and middle adulthood. Even though most seniors avoid direct socio-political references and comments, they express positive attitude towards modern times after the system transformation. However, they also refer, in many ways, to the difficult conditions they experienced as they entered their adult life, began professional careers or started family. One can see indirectly expressed resentment that the realities of their adolescence and adulthood were much worse than today. However, they do not show bitterness or regret due to some historical injustice but rather, paradoxically, they present a cheerful spirit and positive attitude towards the world. Surely, they would like to have lived their lives in socio-cultural and living conditions more like today's but they treat this radical change as a gift given to the young people, something one should be grateful for. Thus, seniors usually appeal to the young people to appreciate the present life conditions which were given to them by the fate and use them for their personal development. Underestimating or wasting this fact would be a grievous loss for the young generation.

(c) The call to reflection on the essential values which give meaning to human life is connected with presentation of authors' own attitudes towards the socio-cultural changes that took place over the years and created new opportunities of functioning of modern humans, their expectations and aspirations connected with these changes and the nature of relationships with other people seen in the context of generations. Seniors in this group kept some emotional distance to the young people (letter recipients), assumed the role of mentors showing what matters in life. They avoided providing biographical facts or describing family members, presenting rather general mechanisms they had observed in the social reality, the mechanisms which determine human life with different strength and demand individual response from everyone.

Messages formulated in this way have many specific references to the values considered timeless, always relevant and, thus, requiring full affirmation during reflection and action. These messages point out to the sphere of vital values like health, utilitarian values such as professional activity as the source of finances and family well-being, and spiritual values identified with openness to others, love, joy of life, responsible accompaniment and support within the family community, delight in the beauty of nature, faith in God that gives sense in life. 


\section{Similarities and Differences in the Letters Written By Polish and Czech Seniors}

During the letter analysis, we considered it cognitively interesting to compare how do seniors from both countries unveil their own biographical perspectives to their young recipients. The question asked by the Polish-Czech research team was what similarities or differences can be found in the letters written by Polish and Czech seniors regarding the ways of exposing personal attitude towards life in the wide time perspective (whole-life perspective). We assumed that letters will show some differences resulting from cultural, religious and mental identity of seniors as well as their historical and socio-political awareness. The comparison involves all categories generated during the content analysis.

Polish seniors focused on the hardships of life, identified with different everyday struggles. They set them in several contexts: living conditions after the World War II, professional career, raising children, deteriorating health, support received from their families or lack of such support. None of the narrators has reflected on the realities of life in the context of worldview and political analyses. Some letters were addressed to persons from outside the family or even to people of similar age and, therefore, with similar biographical experiences.

Czech seniors, in turn, focused on the hardships of life they had experienced as young persons and during their adulthood, and they clearly emphasised their difficulties were connected with the reality of the communist regime in their country during the post-war years right until the socio-political transformation at the beginning of the 1990's. What may come as a surprise, they also clearly declared they believed in God and were convinced that the presence of God brings good - they expressed it in different forms in their messages. Polish seniors were not that open regarding their attitude towards the existence of God and personal declarations of faith. Practically every letter was addressed to someone from the family, from the generation of the grandchildren and great-grandchildren.

Both observations mentioned above are quite surprising if one considers the stereotypes that dominate in Polish, Czech and European media discourse. Poles are presented as founders of the Solidarity social movement which fought communism and as intolerant Catholics who show fundamental religious attitudes. Czechs on the contrary are presented as irreligious, pragmatic and showing open, liberal attitude towards the world. This dichotomy is not confirmed in the analysed letters. Polish seniors concentrate mainly on their professional, family, health, ethical and existential experiences. They abstain from mentioning wider socio-political and religious contexts their life was entangled in. Czech seniors, in turn, focus more on the family as the community which has its history and intergenerational continuity. One can have the impression that they put stronger emphasis on the importance of family in life, also the life of the young generation.

What is interesting is that, apart from traumatic events of the World War II exposed by the Czech seniors (the presence of German soldiers in their country), both Polish and Czech narrators did not refer in their letters to any historical facts from outside their own countries. One Czech narrator mentions the impossibility to 
travel due to political restrictions during communist times. Civil freedoms related to traveling, regained by the citizens of the Central and Eastern Europe after the systemic transformation, especially following joining the EU, are not presented the letters as the elements of biographical experience but as new opportunities or even integral part of life of the young generations.

The definite similarities between the content of the letters written by the Polish and Czech seniors include their sensitivity to other human and the importance of the ethical values in the relationships with other people. The respondents combine the ethical dimension of thinking about others and actions towards others with that what allows them to think about their own lives as at least partly satisfactory. All other aspects of individual activity like education, professional career, material and financial goods are treated as important but subordinate to the ways they could and can support their family members or other people and, in this context, what is worth doing in order to not waste life.

The analysis of the material gathered has also led to the observation that the letters present the key elements assigned to wisdom (Kunzman \& Baltes, 2005), in particular, contextualism of the course of life, deep knowledge of the human nature and life, extensive procedural knowledge regarding responses to life problems and, to a lesser degree, the awareness of the uncertainty of the knowledge possessed, relativism of values and tolerance.

\section{Conclusions}

The analysis of the narrative forms showed differences in the communication patterns constructed by the authors. Seniors presented different ways of "engaging in dialogue" with their recipients. Those who referred to their biographical and family experiences preferred detailed descriptions of family and personal stories from their childhood, adolescence and early adulthood. They showed clear need to share their personal experience from different moments in life, and they did so by recalling part of their biographies in details. Those who referred to socio-cultural aspects and political reality focused on showing the conditions - usually difficult - they had to live in compared to the present realities. The narrative formula is more of a mentor perspective rather than partner. In the communication layer, narratives are based on concise statements which focus on important themes, refer to certain patterns and mental shortcuts and avoid more developed personal references. The main line of the narrative is the intent to draw attention to personal reflections in which seniors try to avoid mentioning their own biographical experiences.

The narrative form reveals the structure of messages adopted in the letters. When focusing on personal biographical experiences, seniors place biographical patterns of behaviours, biographical breakthroughs and sometimes even trajectory experiences in the centre of their message. It becomes their own, personal, wisdom reference to the value and the meaning of life, which is universal. In the narratives which focus on intellectual exploration of life within the social connections and relations, institutional patterns that determine individual choices and chance for self-fulfilment are the central part of the message. In this context, an important contributor to the 
final shape of the wisdom references to the essence of human existence is the critical reflection on the life experience of the significant "Others". This thorough reflection over the complex mechanisms of functioning of the social reality, reflected in the experiences of others, leads seniors to their individual understanding of the value and the meaning of human life.

The content of the letters is, to a large extent, beyond the stereotypical assumptions and expectations. Seniors evaluate their lives in very different ways and choose different categories of their individual biographical experiences as important and worthy to be the central message they share with the representatives of the young generation.

They also build their narratives differently. Some assume the role of mentors who, due to their age and life expertise, look at life from a distance. Others present themselves as friendly companions who have seen and experienced more but are not sure that their experience is universal. They follow their intuition rather than express certainty when showing what is important in life. There are also narrators who share their reflections based on their biographical experiences. But they do not try to formulate their own life message, probably because they do not believe it matters to the young people.

Usually, seniors write about their present health and life situation. They share quite openly about the coming end of their lives in the context of deteriorating health, decreasing ability to secure their daily needs, the necessity to use family or institutional assistance. Despite that, they try to uphold their optimism, stay positive and keep the friendly tone. In general, every letter reveals a hidden, indirect message of the will to live, the need to find the meaning of life and the meaning of own existence in the light of the inevitable death.

The common and dominating elements in the narratives of both Polish and Czech seniors are reflections on the meaning of passing as well as the universal and critical role of the family. These reflection are, of course, connected with the awareness of their advanced age which seniors recognise as the final stage of their life. This motive is expressed as acknowledging the natural order of life and acceptance of the inevitable.

The aspect which surely dominates in the seniors' statements is their strive to identify the value of their life. It lies mainly in the fact of having a successful family life. For them, it is a lasting value and their unique, non-cancellable contribution to the lives of other people. Identifying the essence one's own existence with the value of forming a family through marriage and parenting is associated with timeless presence in the lives of others. It is some form of biological, biographical and even metaphysical being in the perspective of the next generations bound by family relationships. Perhaps, this is the reason why seniors seek fulfilment by focusing on the good of their offspring, especially grandchildren and great-grandchildren. For them, the important element of this good is, on the one hand, the ability to live according to the values which open their mind and hearts to other persons and, on the other hand, the awareness of the family history treated as legacy.

Seniors refer to the family in different contexts and in different ways. Memories of their loved ones - parents, siblings, grandparents or other family members - are the central part of every letter. The importance of family is crucial. It is revealed not 
only in recalling persons and events which symbolize the world long gone, but also in reconstructing the biographical experiences which the authors see as their legacy, as an updated attempt to understand themselves and their place in the rapidly changing world. Thus, family is referred to in the context of the histories of others and their own history, and in the context of "here and now" - the present which binds their fate with the fate of those who have only begun their lives. Family mentioned in the letters is the space of intergenerational, and mental rather than emotional, connections and closeness of its members who are at different levels of the genealogy tree. In the light of the values recognized and respected by the seniors in everyday life, the wellbeing of the youngest generation is understood as identification with and cultivation of the family history and traditions. In this way, accordingly to their biographical experiences and linguistic abilities, seniors show the importance of family; importance which is beyond their life and is identified as the key value of human life.

The tone of most of the letters is optimistic, extremely reserved but never pessimistic. The need to share their experience, knowledge and reflections through the intergenerational communication is the sign of wisdom (Baltes \& Smith, 2008; Sternberg, 1990, 2003), and the act of care about others. The non-intrusive form of the letters and the content which touches the core of what life is about document that what constitutes the essence of life for the narrators. The very fact of engaging in the intergenerational communication fits the category of successful ageing (for example Bülow \& Söderqvist, 2014), is the effect of (gero)transcendence (Torstam, 2005) which reveals itself in the senior years through searching for the ultimate meaning of the (life) events, acknowledging the finiteness of life and approaching the absolute.

Open Access This article is licensed under a Creative Commons Attribution 4.0 International License, which permits use, sharing, adaptation, distribution and reproduction in any medium or format, as long as you give appropriate credit to the original author(s) and the source, provide a link to the Creative Commons licence, and indicate if changes were made. The images or other third party material in this article are included in the article's Creative Commons licence, unless indicated otherwise in a credit line to the material. If material is not included in the article's Creative Commons licence and your intended use is not permitted by statutory regulation or exceeds the permitted use, you will need to obtain permission directly from the copyright holder. To view a copy of this licence, visit http://creativecommons.org/ licenses/by/4.0/.

\section{References}

Addis, D. R., \& Tippett, L. J. (2008). The contributions of autobiographical memory to the content and continuity of identity: A social-cognitive neuroscience approach. In F. Sani (Ed.), Self continuity: Individual and collective perspectives (pp. 71-84). Psychology Press.

Baltes, P. B., \& Smith, J. (2008). Fascination of Wisdom: Its nature, ontogeny and function. Perspectives on Psychological Science. https://doi.org/10.1111/j.1745-6916.2008.00062.x

Baltes, P. B., Glück, J., \& Kunzmann, U. (2004). Mądrość. Jej struktura i funkcja w kreowaniu pomyślnym rozwojem w okresie całego życia. In J. Czapiński (Ed.), Psychologia pozytywna. Nauka o szcześciu, zdrowiu, sile i cnotach człowieka (pp. 117-146).Warszawa: Wydawnictwo Naukowe PWN.

Bednarz-Łuczewska, P., \& Łuczewski, M. (2012). Podejście biograficzne In D. Jemielniak (Ed.), Badania jakościowe. Metody i narzędzia. T. 2. (pp. 91-106). Warszawa: Wydawnictwo Naukowe PWN.

Bogdan, R. C., \& Biklen, S. K. (2003). Qualitative research for education. An introduction to theory and methods. Boston: Allyn \& Bacon. 
Bülow, M. H., \& Söderqvist, T. (2014). Successful ageing: A historical overview and critical analysis of a successful concept. Journal of Aging Studies. https://doi.org/10.1016/j.jaging.2014.08.009

Dryll, E., Tokarska, U., \& Cierpka, A. (2017). Temporal perspective and the transmission of life experience in senility. Psychologia Wychowawcza. https://doi.org/10.5604/01.3001.0011.7853

Fabiś, A., Wąsiński, A., \& Tomczyk, Ł. (2017). Existential perspective of biography - related reflection in the intergenerational narrative messages. Journal of Family History, 43(3), 326-340.

Flick, U. (2007). Managing Quality in Qualitative Research. London, Los Angeles, New Delhi, Singapore and Washington D.C.: Sage.

Kubinowski, D. (2011). Jakościowe badania pedagogiczne. Filozofia. Metodyka. Ewaluacja, Lublin: Wydawnictwo Uniwersytetu Marii Curie-Skłodowskiej.

Kunzmann, U., \& Baltes P. B. (2005). The psychology of wisdom: Theoretical and empirical challenges. In: R. J. Sternberg, \& J. Jordan (Eds), A Handbook of wisdom. Psychological perspectives (pp. 110135). Cambrige: Cambrige University Press.

Lee, C. G. (2012). Reconsidering Constructivism in Qualitative Research. Educational Philosophy \& Theory. https://doi.org/10.1111/j.1469-5812.2010.00720.x

Lichtman, M. (2013). Qualitative Research in Education. A User's Guide. Los Angeles - London - New Delhi - Singapore - Washington DC: Sage Publications.

Lincoln, Y. S., \& Guba, E. G. (2000). Paradigmatic controversies contradictions, and emerging, confluences In: N. K. Denzin, \& Y. S. Lincoln (Eds), Handbook of qualitative research. Thousand Oaks - London - New Delhi: Sage Publications.

Lincoln, Y. S., \& Guba, E. G. (1985). Naturalistic inquiry. Sage Publications.

Mager, B. (2019). Storytelling contributes to resilience in older adults. Activities, Adaptation \& Aging. https://doi.org/10.1080/01924788.2018.1448669.

Mead, M. (1972). Culture and Commitment: A Study of the Generation Gap. Panther.

Patton, M.Q. (1990). Qualitative evaluation and research methods. Sage Publications, Newbury Park London - New Delhi.

Pyszczynski, T., Salomon, S., \& Greendberg, J. (2002). In the Wake of 9/11: The psychology of terror. American Psychological Association.

Staudinger, U. M. (2001). Life reflection: A social-cognitive analysis of life review. Review of General Psychology, 6, 148-160.

Sternberg, R. J. (2003). Wisdom, Intelligence and Creativity Synthesized. Cambridge University Press.

Sternberg, R. J. (1990). Understanding wisdom. In R. J. Sternberg (Ed.), Wisdom: Its nature, origin, and development (pp. 142-159). Cambridge University Press.

Szarota, Z. (2019). Wspólnota wartości w dialogu pokoleń - refleksja pedagogiczna, In: A., ŁacinaŁanowski, \& A. Fabiś (Eds), Dialog międzypokoleniowy. Jubileusz, 20-lecia Oświęcimskiego Uniwersytetu Trzeciego Wieku, (pp. 35-51). Kraków: Impuls.

Tedeschi, R. G., Park, C. L., \& Calhoun, L. G. (Eds.). (1998). Posttraumatic growth: Positive changes in the aftermath of crisis. Lawrence Erlbaum Associates Publishers.

Tokarska, U. (2019). Letter to a grandchild as a narrative tool of older adults' biographical experience exploration. Narrative Inquiry, 29(1), 29-49.

Tornstam, L. (2005). Gerotranscendence. Springer Publishing Company.

Publisher's Note Springer Nature remains neutral with regard to jurisdictional claims in published maps and institutional affiliations.

Artur Fabiś Habilitation in social sciences obtained at the Faculty of Humanities of the University of Szczecin in 2019. Doctor of Humanities in the field of pedagogy, obtained at the Faculty of Humanities, Nicolaus Copernicus University in Toruń in 2003. Andragogue, gerontologist. Coordinator of statutory research at the Pedagogical University of Cracow, author of reports on social research. Research team member of several international research projects (ministerial and EU) on learning in adulthood and old age. Currently, Assistant Professor in the Institute of Educational Sciences at the Pedagogical University of Cracow. Author of the monograph Continuing education in Switzerland (2004), coauthor of the monographs: Ageing and old age in the perspective of social work (2014), Old age in Poland, social and educational aspects (2014), and Human old age, Selected issues of social gerontology (2015), editor and co-editor of 16 multi-author monographs and issues of scientific journals, author and co-author 
of 50 texts in multi-author monographs and scientific journals in Poland and abroad in the field of andragogy and gerontology. His scientific interests focus on the issues of adulthood and aging with particular emphasis on learning, development, as well as existential concerns, support and care in late adulthood. $\mathrm{He}$ is a member of the Editorial Committee of the Andragogical Yearbook, a long-standing member of the Board of Directors of the Academic Andragogic Society, co-founder and Vice-President of the Association of Social Gerontologists, founder and Vice Editor in Chief of the Social Gerontology Library. Initiator and organizer of several scientific conferences, including a series of "Andragogical Conferences". Coordinator of statutory research at the Pedagogical University of Cracow, author of reports on social research. Participant of several international research projects (ministerial and EU) on learning in adulthood and old age. Currently Assistant Professor in the Institute of Educational Sciences at the Pedagogical University of Cracow. Author of the monograph Continuing education in Switzerland (2004), co-author of the monographs: Ageing and old age in the perspective of social work (2014), Old age in Poland, social and educational aspects (2014), and Human old age, Selected issues of social gerontology (2015), editor and co-editor of 15 multi-author monographs and issues of scientific journals, author and co-author of 50 texts in multi-author monographs and scientific journals in Poland and abroad in the field of andragogy and gerontology. His scientific interests focus on the issues of adulthood and aging with particular emphasis on learning, development, as well as existential concerns, support and care in late adulthood. Member of the Editorial Committee of the Andragogical Yearbook, long-term member of the Board of Directors of the Academic Andragogic Society, co-founder and Vice-President of the Association of Social Gerontologists, founder and Editor in Chief of the Social Gerontology Library. Initiator and organizer of several scientific conferences, including a series of "Andragogical Conferences" in Zakopane.

Arkadiusz Wąsiński Assoc. Prof. Professor of the University of Lodz in the Department of Andragogy and Social Gerontology. He is the Deputy Dean of the Faculty of Education Sciences of the University of Lodz, member of the Commission of the University of Lodz for scientific degrees in the disciplines of pedagogy and psychology, also a member of the University Council for the Quality of Education. He is also President of the Association of Social Gerontologists.

He develops his research interests primarily in the areas of self-creation of adults as existentially significant biographical experience, in this context it is self-creation of childless couples to adoptive parenthood, as well as the existential problems of aging and old age educational aspects of communication in the family.

Arkadiusz Wąsiński is the author of 4 scientific monographs, including 1 multi-author, scientific coeditor of 12 collective monographs, author or co-author of 22 scientific publications in scoring foreign and domestic journals, and almost 50 chapters in monographs.

Awarded the "Award for outstanding monographs" by the Board of the Academic Andragogical Society (2019) and the Individual Award of the Rector of the 2nd degree (2016) and the Individual Award of the Rector of the University of Lodz 1st degree (2020).

Together with Dr. hab. Artur Fabis, Prof. UP, he launched the Open Doctoral Seminar for Andragogical- Geragogical Quality Research at the KEN Pedagogical University of Krakow and the University of Lodz.

Oldřich Čepelka (* 1948) A sociologist, worked outside the academic field until 2017 and was engaged in public opinion polls, sociological and economic studies and counselling for non-profit organizations, municipalities, small businesses and local action groups in rural areas (the community-led local development method). He is currently a PhD student in Longevity Studies at the Faculty of Humanities, Charles University in Prague. He deals with the issue of active aging and activities of seniors which have a public impact in municipalities, communities of interest and the whole society. 